\title{
Informasi Kesehatan melalui Leaflet dan Penyuluhan di Desa Kemingking Luar Kecamatan Taman Rajo
}

\author{
Mukhlis Sanuddin ${ }^{1}$, Aldi Dwi Hernawan ${ }^{2}$, Anisar $^{3 *}$, Chervia Oktariani ${ }^{4,}$ Veni Apriliya ${ }^{5}$. \\ ${ }^{1-5}$ Prodi Farmasi, STIKes Harapan Ibu Jambi \\ *Email: anisaraja036@gmail.com
}

Submitted : 17/05/2020

Accepted: 03/08/2020

Published: 24/11/2020

\begin{abstract}
Kemingking Luar Village Taman Rajo District Muaro Jambi Regency is a village that has an area of 820,0000 hectares (hectares) and has a population of \pm 483 people. The border of the village of Kemingking Luar is bordered by the village of Muaro Jambi. Problems in the village of Kemingking Luar namely rheumatism and hypertension, based on field surveys for hypertension and rheumatism in the Village of Kemingking Luar are still very bad because of the work of the majority of farmers. In addition, the survey results also show that family medicinal plants (TOGA) in Kemingking Luar Village have almost 70\% already existed, only the use of TOGA is still lacking because people do not know the benefits and processing of TOGA. for self-medication and to be used as a product of economic value for the people of Kemingking Luar Village, and other problems that occur in Kemingking Luar Village, such as smoking habits, and the lack of community activities to lead a healthy life. Based on this data, students from the Real Work Lecture at Kemingking Luar Village provide counseling and skills to the community of Kemingking Luar Village such as Rheumatism, Gout, Blood Sugar, DAGUSIBU, and Blood Pressure counseling, correct treatment methods, and how to manage TOGA into a TOGA form. valuable and beneficial products for the surrounding community, and utilize TOGA.
\end{abstract}

Keywords: blood sugar, gout, hypertension, moringa leaves socialization, pumpkin toothpick.

Abstrak
Desa Kemingking Luar Kecamatan Taman Rajo Kabupaten Muaro Jambi adalah kawasan desa yang memiliki luas wilayah 820,0000 Ha (Hektar) dan berpenduduk \pm 483 Jiwa. Batas wilayah Desa Kemingking Luar berbatasan dengan Desa Muaro Jambi. Permasalahan yang ada di Desa Kemingking Luar yaitu mengenai rematik dan hipertensi, berdasarkan survey lapangan untuk hipertensi dan rematik di Desa Kemingking Luar masih sangat buruk dikarenakan pekerjaan masyarakat sebagian besar petani. Selain itu hasil survey juga menunjukan bahwa tanaman obat keluarga (TOGA) di Desa Kemingking Luar hampir 70\% sudah ada, hanya saja untuk pemanfaatan TOGA tersebut masih kurang dikarenakan masyarakat belum mengetahui manfaat serta pengolahan dari TOGA tersebut untuk pengobatan sendiri serta untuk dijadikan produk yang bernilai ekonomis bagi masyarakat Desa Kemingking Luar, dan permasalahan lainnya yang terjadi di Desa Kemingking Luar yaitu seperti kebiasaan merokok, dan kurangnya aktivitas gerakan masyarakat hidup sehat. Berdasarkan data - data tersebut, mahasiswa Kuliah Kerja Nyata di Desa Kemingking Luar memberikan penyuluhan dan keterampilan kepada masyarakat Desa Kemingking Luar seperti penyuluhan Rematik, Asam Urat, Gula Darah, DAGUSIBU, dan Tekanan Darah, cara pengobatan yang benar, dan cara pengelolaan TOGA menjadi suatu produk yang bernilai dan bermanfaat bagi masyarakat sekitar, dan memanfaatkan TOGA.

Kata Kunci : asam urat, daun kelor, gula darah, hipertensi, tusuk gigi labu.

\section{PENDAHULUAN}

Desa Kemingking Luar merupakan sebuah pemukiman yang berada dipinggir aliran sungai batang hari. Desa Kemingking Luar disebut dusun Pematang Pauh dan
Selat yang penghuninya sebagaian berasal dari perantauan.

Berdasarkan cerita warga di Desa Kemingking Luar, asal nama Desa kemingking Luar berasal dari kisah seorang yang memiliki ilmu sakti, dimana dia tidak 
bisa meninggal. Pada suatu hari terdapat kabar burung bahwanya jika ingin membunuh orang tersebut, maka harus memisahkan bagian tubuhnya, yaitu bagian kelingking. Menurut cerita kelingking yang dipisahkan tersebut itu sekarang di tanam di Muaro Jambi.

Berdasarkan Data Pokok Desa, sejarah Desa kemingking Luar yaitu berasal dari buah yang dipakai untuk bumbuh masakan bernama buah kemiri, dalam bahasa melayu Kemingking bearti buah kemiri, konon menurut cerita memang batahang pohon kemiri banyak tumbuh didesa kemingking luar, akibat banyaknya membuka lahan untuk pertanian dan perkebunan sampai sekarang ini tanaman tersebut sangat jarang dijumpai, Desa Kemingking Luar berdiri 300 tahun yang lalu sampai sekarang, Desa Kemingking Luar telah melakukan pergantian kepa desa sebanyak 10 kali.

Desa kemingking Luar berada di Kecamatan Taman Rajo di Kecamatan Muaro Jambi. Dengan rata-rata pencarian penduduk Kemingking Luar yaitu Karyawan perusahaan Swasta, serta Petani. Didesa ini terdiri dari 3 RT terbagi menjadi dua dusun yaitu Dusun Selat dan Pematang Pauh, diaman pada desa ini terdapat 123 Kepala Keluarga (KK). Desa Kemingking Luar Kecamatan Taman Rajo Kabupaten Muaro Jambi adalah kawasan desa yang memiliki luas wilayah 480,000 Ha (Hektar) dan berpendudukan \pm 483 Jiwa

Berdasarkan identifikasi masalah yang telah dilaksanakan maka didapatkanlah masalah yang diangkat oleh kelompok sebagai berikut :

a) Gastritis

b) Hipertensi

c) Hiperglikemia

Berdasarkan data yang diperoleh dari Poli Desa dan survei awal, gastritis atau penyakit lambung dan hipertensi adalah penyakit terbesar yang diderita oleh warga desa Kemingking Luar, dimana penyakit ini banyak menyerang semua kalangan baik remaja, dewasa maupun orang tua.
Berdasarkan pendataan warga Desa Kemingking Luar hampir $60 \%$ warga memiliki Tanaman Keluarga (TOGA) dilingkungan rumah. Dari hasil survey yang didapat warga desa kurang peduli dan perhatian terhadap TOGA, kurangnya kesadaran untuk merawat TOGA di lingkungan rumah yang telah ada serta kurangnya pengetahuan masyarakat tentang pemanfaatan dari tanaman obat keluarga sebagai pengobatan tradisional.

Berdasarkan permasalahan desa yang ada khususmya di dusun Selat dan Pematang Pauh maka kami ingin meningkatkan pengetahuan masyarakat desa Kemingking Luar khususnya RT 01 dan RT 02 untuk memanfaatkan alam sebagai sumber pengobatan alami serta mengajak masyarakat untuk berperilaku hidup sehat dan bersih.

\section{TARGET DAN LUARAN}

Pada pengabdian masyarakat yang dilakukan oleh Mahasiswa Kuliah Kerja Nyata (KKN) Sekolah Tinggi Ilmu Kesehatan Harapan Ibu (STIKES HI) Jambi tahun 2020 di Desa Kemingking Luar, dimana target dari Mahasiswa KKN ini yaitu seluruh Masyarakat Desa Kemingking Luar RT.01, RT.02 dan RT.03. Luaran yang diharapkan yaitu agar Mayarakat Desa Kemingking Luar lebih memahami dan mengetahui tentang beberapa penyakit serta cara mengobatinya dengan memanfaatkan tumbuhan obat yang ada di Desa Kemingking Luar.

\section{METODE PELAKSANAAN}

Tempat dan Waktu. Tempat pelaksaan kegiatan ini dilakukan di RT.01, RT.02, dan RT.03, Dusun Selat dan Dusun Pematang Pauh, Desa Kemingking Luar, Kecamatan Taman Rajo, Kota Jambi. Waktu pelaksaan dimulai pada tanggal 2 sampai dengan 24 Februari 2020.

Khalayak Sasaran. Sasaran pengabdian ini antara lain penduduk Dusun Selat dan Dusun Pematang Pauh RT.01, RT.02 dan 
RT.03, Desa Kemingking Luar, Kecamatan Taman Rajo. Semua Masyarakat terlibat langsung dalam kegiatan Pengabdian Masyarkat Mahasiswa KKN STIKES Harapan Ibu Jambi ini.

Metode Pengabdian Metode pengabdian masyarakat ini adalah metodepartisipatori, dimana keberhasilan ditentukan oleh partisipasi dari masyarakat yang menjadi objek sasaran. Masyarakat akan dilibatkan secara langsung dalam proses kegiatan.

\section{Indikator Keberhasilan. Indikator} keberhasilan dari kegiatan ini adalah:

1. Masyarakat dapat mengetahui tentang apa-apa saja penyebab dan gejala gula darah, asam urat dan hipertensi serta bagaimana cara pencegahan dan pengobatan yang baik dan benar.

2. Masyarakat dapat mengetahui tahapan pembuatan tusuk gigi labu, masker dan teh daun kelor. Serta memberikan memberikan informasi tentang menegement pemasaran produk.

3. Siswa/i SD N 230/IX Kemingking Luar dapat mengetahui cara cuci tangan, sikat gigi dan macam-macam obat denga baik dan benar.

4. Terbentuknya Tanaman Obat Keluarga, serta masyarakat mengetahuicara memanfaatkan tanaman tersebut dengan baik dan benar.

\section{HASIL DAN PEMBAHASAN \\ Sosialisasi}

Ketika melakukan sosialisasi di Desa

Kemingking Luar RT.01, 02 dan 03 Dusun

Pematang Pauh dan Dusun Selat,

Kecamatan Taman Rajo menggunakan teori KIE (Komunikasi, Informasi, dan Edukasi). Adapun langkah-langkah yang dilakukan dengan teori KIE yaitu:

1. Penyuluhan Penyakit Gula Darah, Asam Urat dan Hipertensi

a. Melakukan komunikasi terhadap masyarakat tentang penyakit Gula Darah, Asam Urat dan Hipertensi.

b. Memberikan informasi dengan memberikan brosur kepada masyarakat tentang penyakit Gula Darah, Asam Urat dan Hipertensi.

c. Melakukan edukasi kepada masyarakat tentang pengobatan penyakit Gula Darah, Asam Urat dan Hipertensi

2. Penyuluhan DAGUSIBU (Dapatkan, Gunakan, Simpan dan Buang) Obat yang baik dan benar

a. Melakukan komunikasi dan edukasi terhadap masyarakat tentang DAGUSIBU.

b. Memberikan informasi

c. Dengan memberikan leaflet kepada masyarakat tentang DAGUSIBU.

d. Penyuluhan Cuci Tangan dan Gosok Gigi dengan baik dan benar

e. Melakukan komunikasi terhadap anak-anak SD N 230/IX Kemingking Luar.

f. Memberikan informasi kepada anakanak SD N 230/IX Kemingking Luar tentang bahaya yang ditimbulkan jika tidak mencuci tangan dan mengosok gigi dengan benar.

g. Melakuakan edukasi kepada anakanak SD N 230/IX Kemingking Luar dengan harapan mereka terbiasa mencuci tangan dan menggosok gigi dengan baik dan benar sejak dini.

3. Cek Kesehatan

a. Melakukan pengecekan tekanan darah, kadar asam urat, dan kadar gula darah.

b. Memberikan konseling tentang penyakit terkait tekanan darah, kadar asam urat, dan kadar gula darah.

4. Pengembangan TOGA ( Tanaman Obat Keluarga)

a. Melakukan informasi kepada masyarakat mengenai Tanaman Obat Keluarga.

b. Melakukan penambah tanaman dan memperbaiki TOGA. 
c. Melakukan edukasi dengan penyuluhan tentang pemanfaatan Toga ke warga desa.

5. Pembuatan Teh dan Masker Daun Kelor serta Tusuk Gigi Labu

a. Memberikan informasi mengenai manfaat masker dan Teh dari Daun Kelor.

b. Memberikan informasi mengenai cara pembuatan Teh dan Masker Daun Kelor.

c. Mempraktekan langsung mulai dari proses pengambilan sampel hingga penggunaan masker dan teh daun kelor.

d. Memberikan informasi tentang menagement pemasaran dari produk yang dibuat.

\section{Hasil, Evaluasi dan Monitoring}

1. Survei awal

Berdasarkan data di Posyandu

Kemingking Luar tahun 2019-2020, didapatkan hasil bahwa penyakit tertinggi yaitu Hipertensi.. Sedangkan berdasarkan survei awal 3 penyakit terbesar di RT.01, 02 dan 03 yaitu Hipertensi, Asam Urat, dan Gula Darah. Hal ini dikarenakan gaya hidup masyarakat yang kurang baik. Pada kegiatan ini Masyarakat merespon dengan baik dan mau memberikan informasi mengenai penyakit dan cara pengobatan.

2. Penyuluhan Penyakit Gula Darah, Asam Urat, Hipertensi dan Penggolongan Obat

Pada penyuluhan penyakit di RT.01, RT.02 dan RT.03 dihadiri oleh sebanyak 52 orang yang mayoritas ibu rumah tangga, karena anak remaja dan bapakbapak memliki kepetingan masingmasing. Dari 52 orang yang mengikuti penyuluhan masih banyak masyarakat yang belum mengetahui tentang penyakit dan cara pengobatan dari penyakit gula darah, asam urat, hipertensi dan penggolongan obat.

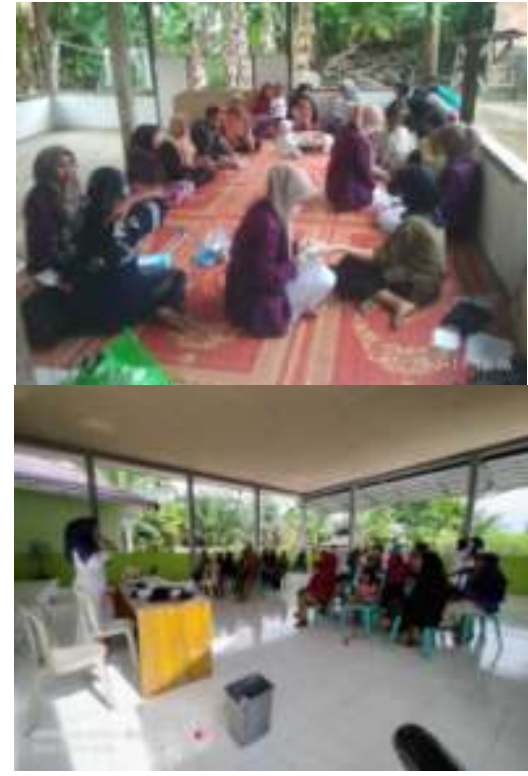

Gambar 1,2 Kegiatan edukasi

Setelah melakukan penyuluhan, dilakukan evaluasi terhadap pemahaman masyarakat mengenai informasi yang diberikan saat penyuluhan. Adanya peningkatan pemahaman masyarakat terhadap penyakit dan penggolongan obat.
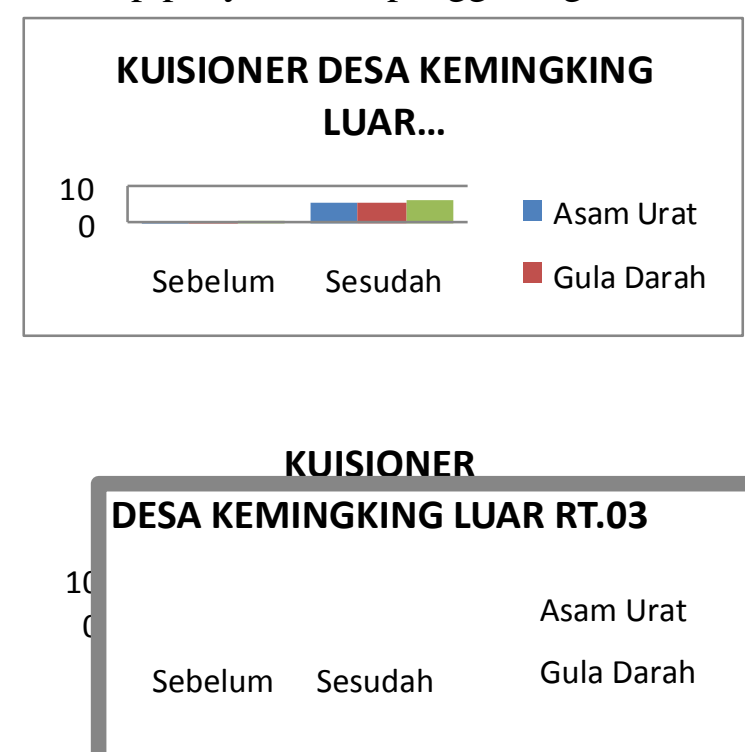

3. Penyuluhan Cuci Tangan dan Gosok Gigi dengan baik dan benar

Anak-anak SD N 230/IX Kemingking Luar banyak yang belum mengetahui cara mencuci tangan dan gosok gigi yang baik dan benar. Selain itu memberikan informasi pentingnya mencuci tangan dengan baik benar dan bahayanya sehingga mengurangi terjadinya diare dan caries gigi pada 
anak-anak. Saat penyuluhan semua siswa/i SD N 230/IX Kemingking Luar sebanyak 48 siswa/i mengikuti kegiatan dengan baik. Setelah di lakukan sosialisasi siswa/i telah memahami cara cuci tangan dan gosok gigi yang baik dan benar.

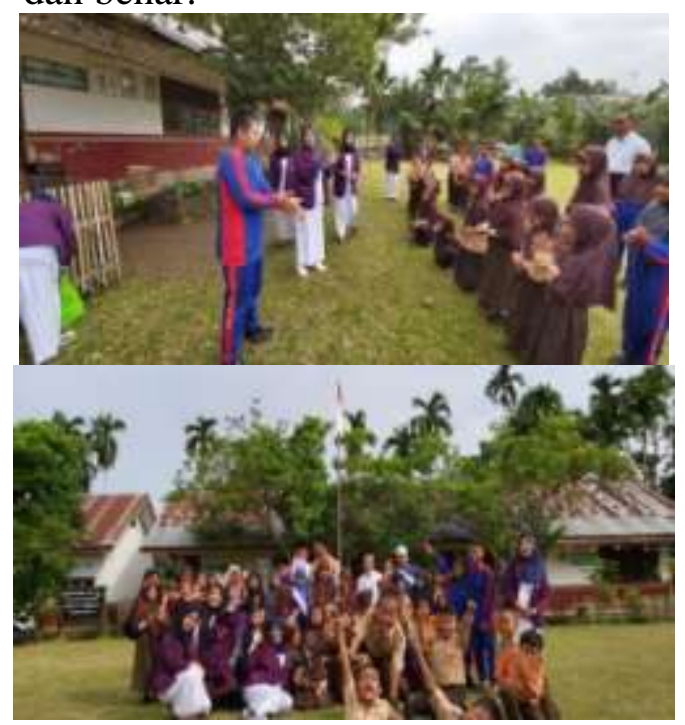

4. Pengembangan TOGA RT 01 dan RT.02 Desa Kemingking Luar telah memiliki Tanaman Obat Keluarga, namun masih kurangnya tanaman herbal dan kurang tertatanya tanaman dengan baik, maka kami melakukan perapian dan penambahan pada tanaman obat keluarga di RT 01 dan RT.02. Penambahan pada tanaman obat 90\% semua tanaman yang ditanam tumbuh denga baik dan dipelihara.

5. Pembuatan Masker dan Teh daun Kelor serta Tusuk Gigi Labu

Pada pembuatan produk masker dan Teh daun kelor, kami memberikan informasi kepada masyarakat dan memberikan contoh langsung pada proses pembuatan produk tersebut hingga penggunaan langsung, dimana respon masyarakat terhadap produk yang kami buat sangat baik, terbukti dengan banyak masyarakat yang tertarik pada produk tersebut.

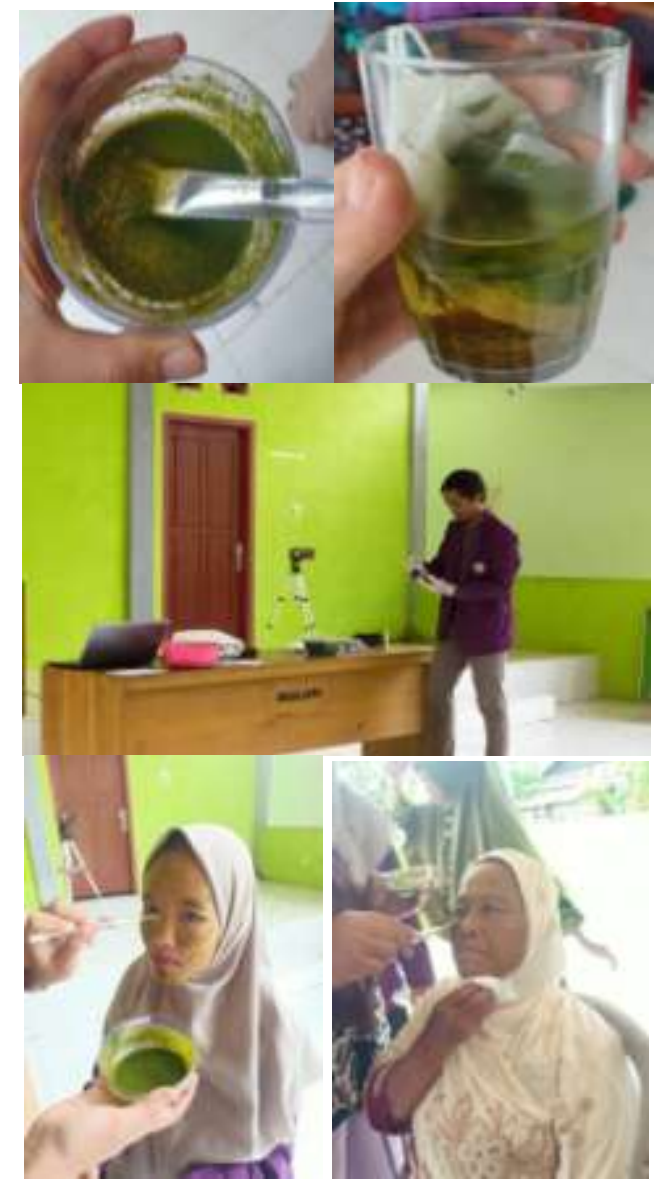

\section{KESIMPULAN DAN SARAN}

1. Kesimpulan

Berdasarkan hasil dan pembahasan maka dapat disimpulkan sebagai berikut:

1. Terlaksananya penyuluhan dan pemberian leaflet dan brosur kepada masyarakat tentang apa-apa saja penyebab dan gejala gula darah, asam urat dan hipertensi serta bagaimana cara pencegahan dan pengobatan yang baik dan benar. Rata-rata pengetahuan masyarakat lebih meningkat setelah dilakukan penyuluhan.

2. Terlaksananya pemberian informasi tahapan pembuatan tusuk gigi labu, masker dan teh daun kelor. Serta memberikan memberikan informasi tentang menegement pemasaran produk. 
3. Tercapainya demonstrasi cuci tangan dan gosok gigi dengan baik dan benar pada siswa/i SD N 230/IX Kemingking Luar.

4. Tercapainya pengembangan dan perapian toga, serta informasi tentang manfaat tanaman.

5. Penyuluhan tentang penggolongan obat dan didapatkan rata-rata pengetahuan masyarakat lebih meningkat setelah dilakukan penyuluhan.

Tercapainya pelaksanaan cek kesehatan berupa tekanan darah, asam urat dan gula darah..

\section{Saran}

Berdasarkan pengalaman mahasiswa KKN di Desa Kemingking Luar yaitu lebih melengkapi fasilitas kesehatan dan tenaga kesehatan yang ada di Desa Kemingking Luar.

\section{UCAPAN TERIMAKASIH}

Terimakasih penulis ucapkan kepada seluruh pihak yang telah membantu selama proses pengabdian masyarakat mahasiswa Kuliah Kerja Nyata Sekolah Tinggi Harapan Ibu Jambi tahun 2020.

\section{DAFTAR PUSTAKA}

Depkes RI.2006.Pharmaxetikal care untuk penyakit hipertensi. Jakarta
Depkes RI.2005.Pharmaxetikal care untuk penyakit diabetes millitus. Jakarta

Depkes RI.2006.Pharmaxetikal care untuk penyakit arthritis rematik. Jakarta

Hidayat, A. aziz alimul, \& Mustifatul, U. (2004). Kebutuhan Dasar Manusia. Jakarta: EGC

Misnadiarly. (2009). Mengenal Penyakit Organ Cerna. Jakarta : EGC

Perdana, R. S., Furqon, T., \& Putri, D. (2017). Klasifikasi Penyakit Kulit Pada Manusia Menggunakan Metode Binary Decision Tree Support Vector Machine ( BDTSVM ) ( Studi Kasus : Puskesmas Klasifikasi Penyakit Kulit Pada Manusia Menggunakan Metode Binary Decision Tree Support Vector Machine ( BDTSVM ) (. Jurnal Pengembangan Teknologi Informasi Dan Ilmu Komputer, 2, 1912-1920.

Purnama, S. G. Buku Ajar Penyakit Berbasis Lingkungan (2016). Jakarta :EGC 